Copyright (C) 2018 by the Kalmyk Scientific Center of the Russian Academy of Sciences

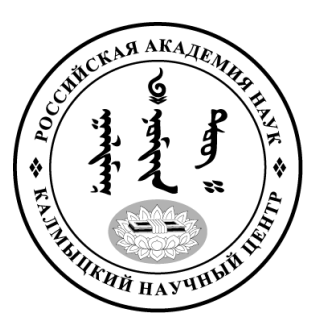

Published in the Russian Federation

Oriental Studies (Previous Name: Bulletin of the Kalmyk Institute for

Humanities of the Russian Academy of Sciences)

Has been issued as a journal since 2008

ISSN: 2619-0990; E-ISSN: 2619-1008

Vol. 40, Is. 6, pp. 110-119, 2018

DOI 10.22162/2619-0990-2018-40-6-110-119

Journal homepage: https://kigiran.elpub.ru

УДК 811.512 .31

\title{
Грамматика монголо-бурятского разговорного языка А. М. Орлова: Глагол. Категория залога
}

Полина Петровна Дамбуева ${ }^{1}$

${ }^{1}$ доктор филологических наук, ведущий научный сотрудник, отдел урало-алтайских языков, Институт языкознания РАН (125009, г. Москва, Российская Федерация, Большой Кисловский пер., д. 1., стр. 1). ORCID: 0000-0003-1948-7149. E-mail: polina-dambueva@mail.ru

\section{Аннотация}

Цель. Статья посвящена «Грамматике разговорного бурят-монгольского языка», написанной А. М. Орловым в 1878 г. «Грамматика...» А. Орлова была написана как практическое руководство для изучения бурятского языка в связи с необходимостью повышения уровня переводов литературы религиозного содержания.

Цель данной статьи заключалась в рассмотрении категории залога в «Грамматике...» в сопоставлении с фактами современного бурятского языка, в сравнении языкового материала «Грамматики» с современным состоянием залога. В ходе описания автор стремился осветить научный подход А. М. Орлова к составлению грамматики бурятского языка: в «Грамматике...» рассмотрены все разновидности бурятского залога, способы выражения, маркированность и частично - полисемия маркеров. Во Введении к разделу «Глагол» А. М. Орлов делит глаголы на первообразные и производные, демонстрируя разницу на обширном материале, обнаруживая глубокое понимание структуры бурятских глаголов, образованных от имен, наречий и частиц, что для не-носителя языка было в то время редкостью. Автор грамматики также ставил перед собой цель устранения искажений в написании и произношении бурятских слов под влиянием маньчжурских и китайских языков в результате их контактирования с бурят-монгольским.

Memodbl. В работе применена комплексная лингвистическая методика, позволяющая с разной степенью использовать сравнительно-исторический, описательный методы, метод структурного сопоставления, структурного анализа, метод наблюдения.

Актуальность темы объясняется неоднозначностью залоговых показателей, связанной со смешанным, лексико-семантическим характером данной категории, что заставляет исследователей искать решения проблемы залога с привлечением разных уровней языка.

Результаты. В статье выявлено, что в «Грамматике...» А. М. Орлова даны очень точные характеристики залогов бурятского языка конца XIX в., подробно перечислены и описаны морфологическиепоказателизалогов, аиллюстративныйматериалсвидетельствуетодостаточно глубоком знании автором лексического своеобразия и особенностей грамматического строя бурятского языка. В результате рассмотрения «Грамматики...» можно констатировать, что суффиксы - маркеры залога в бурятском языке - сохранились в неизменном виде по истечении почти полутора столетий со времени написания рассматриваемой грамматики. При анализе залога в современном бурятском языке выявлено: трудно утверждать, что морфологические показатели залога однозначно передают значение того или иного залога. Так, например, суффиксы побудительного залога могут иметь страдательное значение, и для дифференциации этих значений может быть привлечён семантико-синтаксический уровень языка. Достаточно часто -ldu со значением взаимного действия может быть заменено на форму совместного действия на $-l c a$ без ущерба для смысла предложения. В современном бурятском языке значения залога нередко передаются синтаксическим способом. 
Bblвoдbl. В современном бурятском языке глагольные суффиксы, перечисленные в «Грамматике разговорного бурят-монгольского языка» А. М. Орлова, получили дальнейшее развитие, пополнилась их таксономия, а сама категория залога рассматривается в свете более широкой лексико-грамматической категории.

В статье делаются выводы о необходимости рассмотрения залога с точки зрения его разноуровнего выражения; дается описание малоизученных залоговых форм на -оотой, -ээтэй, -аатай, возникших, как считает автор, под влиянием русского языка.

В бурятском языке, как и в других монгольских языках, при передаче грамматических значений в слове часто наблюдается влияние лексического значения его основы - особенно в тех случаях, когда грамматическая категория не имеет специализированных, регулярных средств выражения. Категория залога, в котором план выражения и план содержания асимметричны - наглядное тому подтверждение: в настоящее время всё чаще приходится говорить не столько о залоге, сколько о залоговости - функционально-семантическом поле, в котором образуются микрополя лексико-грамматических разрядов, объединенных общностью семантических признаков.

Ключевые слова: А. М. Орлов, грамматика, монголо-бурятский язык, современный бурятский язык, залог, категория залоговости, грамматические показатели

Составитель «Грамматики» А. М. Орлов в предисловии даёт её обоснование, которое вкратце может быть сведено к следующему: 1) обновление бурят «достигалось бы с большею быстротою, если бы влияющие на них из нашей среды личности вооружены были основательным знанием живого бурятского языка» [Орлов 1878: 5]; 2) говоры бурятского языка очень сильно расходятся с книжным монгольским языком, «на котором имеются, в переводе с тибетского, священные книги и ведется у забайкальских ламаистов деловая и даже приятельская переписка» [Орлов 1878: 5-6]. Простые буряты «при чтении письменно-монгольских слов могут вовсе не понять их» [Орлов 1878: 6]. Причину этих расхождений А. Орлов видит в «искусственной и неудовлетворительной азбуке», устарелости форм и «забвении бурятами слов, в книгах монгольских встречающихся непрестанно» [Орлов 1878: 6]; 3) говоря о том, что нет единообразия и в говорах бурятского языка, автор делает краткий обзор главных наречий с попыткой дать их классификацию, выделяя селенгинское наречие (характерное для халхасских монголов, переселившихся из монгольских аймаков в конце XVII в.) и балаганское наречие, на котором говорят «по ту сторону Байкала» - хоринские, кударинские, баргузинские буряты, и «по эту сторону Байкала» - тункинские, аларские, идинские, кудинские, ленские, верхоленские и ольхонские буряты; 4) переводы статей и брошюр религиозного содержания с языка русского на монгольско-бурятский, по мнению А. М. Орлова, страдают «произволом записчиков ... произвол - нередко произносящий, пишущий, изменяющий одно и то же слово на разные манеры» [Орлов 1878: 7]; 5) А. М. Орлов отмечает, что «разные изделия монголов, например, их разговоры, напечатанные параллельно с разговорами маньчжурскими и китайскими», отличаются подражанием: «руководясь азбукою маньчжуров, общие монголам и бурятам звуки и слова пишут сообразно с произно-

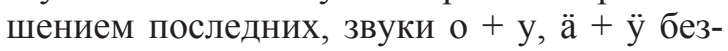
отчётно смешивают, подражая притом даже в расположении и сочинении слов» [Орлов 1878: 7]. В связи с этим автор при написании своей «Грамматики» опирался на язык таких произведений, как «Гэсэр хан», «Алтан тобчи», «Сананг Сэцэн», чтоб исключить иноязычное влияние.

\section{Введение к разделу «Глагол»}

В разделе «Глагол» «Грамматики бурят-монгольского разговорного языка» А. М. Орлова выделены в отдельную рубрику глаголы первообразные - «не происходящие от имён, частиц или происходящие от них, но без особых характеристических надбавок» [Орлов 1878: 54]:

$$
\begin{aligned}
& \text { да 'следуй' } \\
& \text { хай 'теши' } \\
& \text { ол 'находи' } \\
& \ddot{y m} \text { 'умножайся' } \\
& \text { алху 'шагай' } \\
& \text { гоё 'украшайся' [Орлов 1878: 54-57]. }
\end{aligned}
$$

Производные глаголы - образовавшиеся от имён и частиц «при пособии особливых наращений, придающих особливый от- 
тенок их значению» [Орлов 1878: 54-55]: алтан 'золото' - алтала 'золоти',

бӧ 'шаман' - бӧлэ 'шамань',

хйл 'нога' - хӥллэ 'ходи на своих ногах', $\partial \bar{y}$ 'голос' - $\bar{y} \boldsymbol{\partial} \boldsymbol{a}$ 'призывай, читай',

ойра 'близкий' - ойрада 'приближайся', харангуй 'тьма, мрак' - харангуйта 'омрачайся',

манан 'туман' - манара 'туманьс',

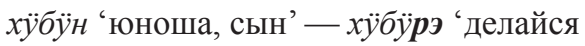
мальчиком',

хуррин 'жительство' - хуруринша 'жительствуй',

хан 'царь' - ханжи 'царствуй,

эбйл 'зима' - эбӥлзэ 'зимуй',

холо 'далёкий' - холот 'отдаляйся’,

нигэ 'один' — нигэт 'объединяйся',

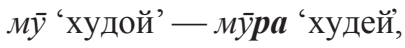

дӥлэй ‘глухой’ - дӱлэрэ 'глохни’,

залу 'молодой' - залуиши 'молодей',

хату 'твёрдый' - хатужжи 'твердей',

орой 'поздно' - оройта 'опаздывай’ [Орлов

1878: 55-57].

Судя по данным этого перечня слов, автор опирался здесь на лексику, по его терминологии, «балаганского» наречия, так как признаки цонгольского, сартульского, т. е. южно-бурятских, говоров в виде аффрикат $u, \partial 3, ч, \partial ж$ вместо щелевых ж, $u, 3, c$ не наблюдаются. Косвенно об этом свидетельствуют отсутствие графемы $\kappa$, долготы согласных, палатализации согласных в начале слова перед $u, u u, a, o, Y, Y Y$, конечного 'оканья'. Присутствуют признаки 'Һакающего' говора, характерные для восточно-бурятских и западно-бурятских диалектов: в словах $x \bar{y}$ сага 'посиживай', например [Орлов 1878: 61], хурурин 'жительство'хурринша 'жительствуй' [Орлов 1878: 57], не обнаруживается начального $c$, а $x$ в начале слова, вероятно, следует воспринимать как способ передачи экзотического $h$.

Из приведённого списка наибольшее развитие в современном бурятском языке получил суффикс -ла (-лэ, -ло), который используется во многих случаях образования глагола от имён существительных; этот суффикс вносит в образовавшийся глагол значение «действие, производимое над названным объектом»:

тамга 'печать' - тамгалаха 'поставить печать,

шүдэр 'путы' - шүдэрлэхэ 'надевать (на ноги животного) путы,'

хүреэ 'забор' - хүреэлэхэ 'огораживать забором’.
В отдельных случаях суффикс -ла может выступать в варианте -л: алтан 'золото' [Орлов 1878: 55] — алтал 'золотить, покрывать позолотой; украшать золотом' [Шагдаров, Черемисов 2006: 55].

Большое распространение суффикс -л вместо -ла, -лэ, -ло получил в баргузинском говоре современного бурятского языка: «Глаголы [в баргузинском говоре] образуются посредством суффиксов: 1) -л (лит. -ла, -ло, -лэ): мулталха 'сорвать', зугаалха 'разговаривать'...» [Раднаев 1965: 103], а также в литературном бурятском, особенно в связи с освоением заимствований из русского языка: борной 'борона' - борнойлхо 'боронить', электрификаци 'электрификация' электрификацилха 'электрифицировать', бетон - бетонлохо 'бетонировать.'

Алтан 'золото' [Орлов 1878: 55] в современных диалектах употребляется ещё с суффиксом -ma в глаголе: алтатаха 'золотиться, отливать или искриться золотом' [Шагдаров, Черемисов 2006: 56]. Суффикс -та (-то, -тэ) в глагольном словообразовании вызван к жизни, вероятно, отсутствием морфологических показателей возвратного залога в бурятском языке, в котором на данном этапе залоговость развивается в русле образования в её микрополях лексико-грамматических категорий на основе общности семантических признаков: буриmaxa 'покрываться плесенью' от бури 'плесень', mоohотохо 'пылиться' от тооһон 'пыль', мүльһэтэхэ 'покрываться льдом' от мүльһэн 'лёд', хөөһэтэхэ 'пениться' от хөөһэн 'пена'.

О расширении состава глагольных суффиксов на современном этапе можно судить и по другим дериватам:

харангуйта 'омрачайся' от харангуй 'тьма, мрак' [Орлов 1878: 57] - харанхыда 'темнеть, перен. мрачнеть, омрачаться' от харанхы 'темнота, мрак'; харанхыла-, харанхылуул-, харанхыдуул- 'загораживать свет, затемнять' [Шагдаров, Черемисов 2008: 402].

манара 'туманиться' от манан 'туман' [Орлов 1878: 57] — манатаха 'покрываться туманом, туманиться', манаруулха 'затуманивать' [Шагдаров, Черемисов 2008: 535].

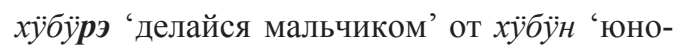
ша, сын' [Орлов 1878: 57] - хүбүүншэлхэ 'принимать чужого ребёнка за своего сына'; хүбүүрхэхэ 'хвастать, быть довольным тем, что есть сын; хвастать своим сыном'; хүбУҮшэлхэ 'усыновлять'; ХүбУУшээхэ 'считать сыном, перен. относиться пристрастно, 
выделять, поддерживать' [Шагдаров, Черемисов 2008: 478].

Залоги глагола. Побудительный залог Называя этот залог 'переносным', А. М. Орлов даёт ему следующее определение: «Переносный, означающий действие, предоставляемое другому...» [Орлов 1878: 59]. Для образования форм данного залога в Грамматике употреблены следующие маркеры:

1) -ю̄л после гласной $u$, оканчивающей корень глагола, с поглощением этой гласной [Орлов 1878: 59];

хори 'запрещай' - хорю̄л 'вели запрещать' [Орлов 1878: 57], лит. хорюул 'заставить запретить';

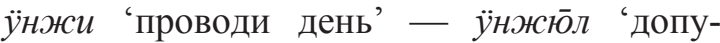
сти провести день' [Орлов 1878: 59], лит. ҮнжүҮл 'разрешить провести день';

2) $-\bar{y} л, \bar{y} л$ после других гласных, с поглощением этих гласных [Орлов 1878: 59]: хоно'ночуй' — хонӯл 'допусти переночевать’ [Орлов 1878: 59], лит. хонуул 'оставить (у себя) переночевать';

эжилэ 'обладай' - эжилї 'будь обладаем' [Орлов 1878: 59], лит. эжилүүл 'позволить владеть', 'заставить владеть' (в зависимости от контекста).

В современном бурятском языке указанным в Грамматике маркерам переносного, по А. М. Орлову, залога соответствуют показатели побудительного залога -уул, -юул, -ҮYл, употребляемые после глагольных основ на краткий гласный, а если слово многосложное - ещё и на сонорные согласные:

ерэ 'приходить'- ерүүл 'велеть прийти', оро 'входить' - оруул 'заставить войти' боли 'переслать' - болюул 'заставить прекратить'.

3). -лга, -лгэ [Орлов 1878: 60]: бу 'спускайся' - булга 'спускай', лит. булга 'спускаться, опускать';

обой 'наполняйся' — обойлга 'наполняй' [Орлов 1878: 60], лит. обойлго 'заставить возвышаться';

гйй 'беги' - гёлгэ 'вели бежать' [Орлов 1878: 60], лит. гүйлгэ 'заставить бежать'.

В современном бурятском языке суффиксы -лга-, -лгэ-, -лго- присоединяются к переходным и непереходным основам глаголов, оканчивающимся на долгий гласный или дифтонг: $y y$ - 'пить' - уулга- 'заставить пить '; харай 'прыгать' - харайлга 'заставить прыгнуть'.

Из истории современных суффиксов побудительного залога известно, что суффикс

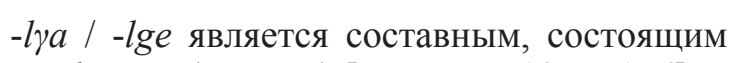
из -l и -ga (-ge, -go) [Рамстедт 1957: 156]; в монгольских текстах XIII-XIV вв. суффикс -л был еще живым, продуктивным [Санжеев 1964: 27]. Это положение подтверждается данными древнемонгольских текстов: форма побудительного залога от глагола

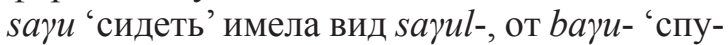
скаться' - bayul-, т. е. во времена их написания суффиксом этого залога был -л (см.: [Рамстедт 1957: 151; Санжеев 1964: 33]).

4) -га, -гэ: уна 'падай' - унага̄ 'роняй' [Opлов 1878: 59], лит. унагаа- 'уронить',

бол 'делайся' - болга 'делай' [Орлов 1878: 60], лит. болго- 'делать (таким)',

хӧр 'мёрзни' - хӧргэ 'морозь' [Орлов 1878: 60], лит. хүргэ- 'замораживать';

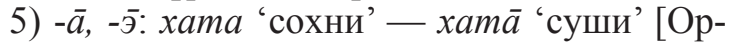
лов 1878: 59], лит. хатаa- 'сушить',

ӱлэ 'оставайся' - ӱлэ 'оставь' [Орлов 1878: 60], лит. Үлээ- 'оставить'.

Bce суффиксы каузатива, перечисленные А. Орловым, в современных диалектах бурятского языка продуктивны. Это касается прежде всего суффиксов -уул, -юул, -ҮYл, -лга, -лго, -лгэ, которые замечены ещё в самых древних текстах в побудительном значении: mukurigul- 'заставить кувыркнуться' [Veitz, Lubsang 1992: 38], sagulga- "посадить' [Veitz, Lubsang 1992: 17], kodelge- 'заставить шевелиться' [Veitz, Lubsang 1992: 33], beceulbe tundu 'заставил его писать' [Поппе 1938: 118], nu'ulgebe tuni 'заставил его переселиться’ [Поппе 1938: 262].

Что касается суффиксов -га, -гэ (-xa, $-x o),-\bar{a},-\bar{y},-\bar{o}$, упомянутых в Грамматике А. М. Орлова, в некоторых работах по современному бурятскому языку высказывается мнение, что данные суффиксы лишь переводят глаголы в разряд активных, т. е. они приобретают способность управлять именем, но не побудительное значение: бодо- 'вставать, подниматься' [Орлов 1878: 59] - туг бодхоохо 'установить знамя', гара- 'выходить' [Орлов 1878: 58] - шкаф гаргаха 'шкаф выносить (из кабинета)'.

«Будет более правильным полагать, что суффиксы $-x a,-z a,-a a$, не являясь суффиксами побудительного залога, - пишет Г. Д. Санжеев, - служат лишь для образования переходного глагола от непереходного» [Санжеев 1941: 65], (см. также: [Цыдендамбаев 1979: 94-95]).

Неслучайно глаголы с побудительными суффиксами - $x a,-2 a,-a a$ в тункинском, баргузинском говорах (в эти районы были орга- 
низованы нами экспедиции в 2015-2016 гг. с последующей обработкой данных в системе ПРААТ), а также в боханском, осинском говорах современного бурятского языка в разговорной речи употребляются «усиленные» каузативные формы: хатуy 'твёрдый' [Орлов 1878: 57] — хатуудхуул- 'заставить делать более твёрдым' (за 'недостаточностью’ суффикса - $а$ за ним добавлен суффикс побудительного залога -уул), лит. хатуудха- 'делать твёрдым'; гар 'выходи' [Орлов 1878: 58] - гаргуул- 'заставить вывести', лит. гарга- 'выводить'; хата̄ 'суши' [Орлов 1878: 59] - хатаалгуул- 'заставить сушить', лит. хатаалга-; нигэт 'объединяйся’ [Орлов 1878: 57] - нэгэдхүүл- 'заставить объединиться', лит. нэгэтхэ- 'соединяй'.

\section{Страдательный залог}

Страдательный залог в Грамматике А. М. Орлова определён как «...высказывающий обыкновенно страдание предмета» [Орлов 1878: 60]. Для образования страдательного залога в памятнике приведены следующие суффиксы:

1) $к \partial а-\kappa \partial э:$

лабла 'одобряй' - лаблакда 'будь одобряем’ [Орлов 1878: 60], лит. лаблагда- 'проверяться, подвергаться проверке (или уточнению)' от от лабла 'удостоверяться, уточнять, выяснять';

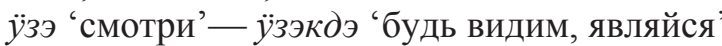
[Орлов 1878: 60], лит. Үзэгдэ- 'быть видимым';

гар 'выходи' - гаргакда 'будь выводим' [Орлов 1878: 60], лит. гаргагда 'быть выведенным (или вынесенным)';

нугура 'гнись' - нугуруулакда 'будь перегибаем' [Орлов 1878: 60], лит. нугарагда ‘быть сгибаемым';

2) да-дэ: ол 'находи' - олда 'будь находим' [Орлов 1878: 60], лит. олдо 'быть найденным, обнаруживаться.'

В современном бурятском языке морфологическим ядром пассива являются глагольные формы с суффиксами:

1) -гдэ (-гда, -гдо): неэгдэхэ 'быть открытым', баригдаха 'быть схваченным', мохоогдохо 'быть укоряемым'. Данные суффиксы присоединяются к глагольной основе, оканчивающейся на гласный.

2) -да (-до), если основа глагола оканчивается на согласный -л: дуула- 'слушать'дуулдаха 'быть слышимым';

3) -ma (-тэ), если основа оканчивается на гласные, согласные $\sigma, 2, p$ и сонанты: абтаха 'быть взятым', үгтэхэ 'быть отданным’. Как уже было отмечено выше, иногда такие глаголы имеют дополнительное значение, например: аюулта$x a$ 'подвергаться опасности', яратаха, нурөөтэхэ, алагтаха, дабһатаха, хүлхэнтэхэ, замагтаха 'покрыться болячками, оспинами, полосками (пестринками), солью, вмятинами, тиной (водорослями)';

4) -оотой, -ээтэй, -аатай (фонетические варианты -өөтэй, -еэтэй, -яатай): оёотой 'сшитый', хушаатай 'укрытый'. Эти малоизученные формы образованы от причастий простого прошедшего времени с помощью флексии совместного падежа -тай: бэшэ 'писать' - бэшээ 'написавший' - бэшээтэй 'написанный’. В списке суффиксов, данных в работе Г. А. Дырхеевой и О. С. Ринчинова, комплексы $a a+$ maй, оо + той, ээ + mэй рассматриваются как один суффикс [Дырхеева, Ринчинов 2005: 23], с чем, вероятно, следует согласиться, так как, в отличие от аффикса совместного падежа -тай (унеэтэй, бэлигтэй), -тай в причастиях хушаатай, үлгээтэй вместе с предыдущими аффиксами - $a a$, -ээ, -оо выражает значение 'подвергшийся действию со стороны, содержащий результат этого действия, который актуален в момент речи'. Именно тому, что в семантике данных причастий на первый план выступает действие и его результат, а не производитель действия, конструкции с причастным пассивом обязаны своим рецессивным характером: Дугар мяха шанаба 'Дугар сварил мясо' - Мяхан шанаата 'Мясо сварено'. ${ }^{1}$

1 Формы на -аатай (-ээтэй, -оотой) синкретичны: признаки глагола грамматически выражаются в наличии категорий времени, вида, залога, в сохранении модели глагольного управления и примыкания; в контексте формы на -аатай, -оотой, -ээтэй выполняют функцию сказуемого, образуют аналитическую форму. И в то же время эти формы могут быть использованы в атрибутивной функции - в качестве определения: хушаатай модон орон 'покрытая (пледом) деревянная кровать'. Атрибутивное и предикативное употребление этих глагольных словоформ может быть дифференцировано порядком слов в словосочетании: Дэгэлни оёотой — hаянай оёотой дэгэл 'Пальто (мое) сшито Недавно сшитое пальто’. Формы типа уяатай, 
5) В современном бурятском языке получило большое распространение выражение значения страдательного залога с помощью показателей побудительного залога -уул, -юул, -Үүл: уул/юул (сохюулаха 'быть избитым', татуулаха 'быть притянутым', зэмэлуулхэ ‘быть обвиненным'). Явление это широко распространено в художественных произведениях. Приведём примеры из романа Батожабая «Похищенное счастье»: Бажуулгаһан хунууд тэрэниие тойрошоод, хараажа захалба 'Его окружили люди, которых он щипал, и стали [его] ругать'. Букв.: 'щипанные люди'. Шинии солдадууд

бэшээтэй можно, вероятно, квалифицировать как нефинитную форму глагола - причастие, a c учетом «страдательной» семантики - как страдательное причастие. В пользу этого вывода говорят следующие признаки пассива:

а) в предложениях с причастиями на -аaтай, -оотой, -ээтэй нет соответствия семантического объекта подлежащему, что является основным признаком пассивной конструкции. Пассивные конструкции в современном бурятском языке рассматриваются как объектно-ориентированные, так как преобразование активной конструкции в пассивную реализуется посредством рематизации субъекта и тематизации объекта, т. е. к трактовке пассива привлекаются семантические категории, релевантные для залога;

б) в конструкциях с рассматриваемыми причастиями представлен такой структурно-синтаксический признак пассива как наличие или возможность распространения предложения субъектным дополнением;

в) пассивной является общая ориентация действия: оно совершено «кем-то со стороны» и направлено на объект.

Суффиксы -аaтай, -оотой, -ээтэй служат показателем пассива, однозначно маркируя уход субъекта с позиции подлежащего. На это указывают, кроме названных выше признаков, унифицированный характер формы и специализация на выражении пассивного значения. Эта специализация настолько выражена, что аффиксы -aатай, -оотой, -ээтэй могут нейтрализовать значение другого суффикса: их присоединение, например, к форме побудительного залога подавляет побудительную семантику, придавая глагольной словоформе отчетливое значение пассива: Үудэ хаалгаха 'попросить, заставить (коголибо) закрыть дверь' / ҮҮдэн хаалгаатай 'дверь закрыта'. Үнеэ һаалгаха 'попросить, заставить (кого-либо) подоить корову’ / Үнеэн һаалгаатай 'корова подоена'. мэхлуулээ! 'Твои солдаты обмануты!' Хэн суудлуулхэб? 'Кто пойдет под суд?' Гэшхуулжэ байһан Буладые ...'Булата, которого топтали...' Орохо газар угы болоод улдуулюжэ... 'Потеряв пристанище, гонимая...' Намнуулһан байгаa ‘был выгнан' [Батожабай 1959].

Употребление -уул, -юул для выражения двух разных залогов отражено и в словарях. Например, в бурятско-русском словаре К. М. Черемисова форма мүргүүлхэ имеет следующие значения: 1) заставлять кланяться; 2) быть бодаемым [Черемисов 1973: 308].

Отмеченная неоднозначность вместе с многозначностью глагола создает трудности в распознавании залоговых форм, т. к. у глаголов с суффиксами -уул, -юул есть потенциальная возможность выступить как в каузативной, так и в пассивной реализации.

\section{Взаимный залог}

Этот залог представлен в «Грамматике» как «...показывающий одинаковое участие в действовании двух лиц, или сторон» [Opлов 1878: 60]. Приводятся примеры с суффиксами совместного залога -лда/-лдэ:

хурхира 'храпи' - хурхиралда 'все храпите,

мӥргӱ 'кланяйся' - мӥргӥлдэ 'все кланяйтесь' [Орлов 1878: 61].

Реципрок обладает следующими признаками: а) каждый актант реципрокальной конструкции выполняет две симметричные роли; б) обе роли выполняются одновременно (ср. с совместным залоговым значением, в котором одновременность понимается относительно, как в «пределах данной ситуации», а степень участия и момент участия «содействователя» не обозначены).

Во всех определениях, которые даются взаимному и совместному залогам в грамматических работах по монгольским языкам, справедливо подчеркиваются такие наиболее яркие их стороны, как «направленность действия друг на друга» в реципрокальных конструкциях и маркированную суффиксом глагола неединичность исполнителя одного действия в социативе (см., например: [Цыдендамбаев 1979: 108, 111; Санжеев 1964: 57-58].

Взаимный залог в современном бурятском языке обычно образуется от основ активных глаголов при помощи суффикса -лда (-лдэ, -лдо): бур. носолдохо 'драться', турсэлдэхэ 'толкаться', мухарилдаха 
'кувыркаться' (монг. иивнэлдэх 'шептаться', дайралдах 'встречаться' и т. п.; калм. мөрглдх 'бодаться', сэгсрелдх 'схватиться (друг за друга)’.

\section{Совместный залог}

А. М. Орлов называет данный залог учаственным, что в принципе не противоречит известным в литературе определениям социатива: Ц. Б. Цыдендамбаев, например, совместный залог называл содействованным, так как характеризуемый залог обозначает «участие субъекта в действии, совершаемом иным исполнителем, или попутным действием, выполняемым субъектом наряду с основным действием» [Цыдендамбаев 1979: 109].

Автор данный залог демонстрирует такими примерами [Орлов 1878: 61]:

на̄дy 'играй — на̄дулса 'вместе играй, лит. наадалса- 'играть вместе'

хэлэ 'говори' - хэлэлсэ 'разговаривай, лит. хэлэлсэ- 'говорить вместе'

хӧр 'мёрзни' - хӧрүлсэ 'вместе мёрзни, лит. хүрэлсэ- 'мёрзнуть вместе'.

Названные А. Орловым суффиксы -лса, -лсэ, -лсо в современных бурятских диалектах остаются основными маркерами совместного залога.

\section{Заключение}

Таким образом, в грамматике А. М. Орлова даны очень точные характеристики залогов бурятского языка конца XIX в., подробно перечислены и описаны морфологические показатели залогов, а иллюстративный материал свидетельствует о достаточно глубоком знании автором лексического своеобразия и особенностей грамматического строя бурятского языка. По истечении около полутора столетий со времени написания описываемой грамматики можно констатировать, что суффиксы - маркеры залога в бурятском языке - сохранились в почти неизменном виде ещё с древних времён ${ }^{1}$.

${ }^{1}$ В дошедших до нас памятниках среднемонгольского периода (периодизация Б. Я. Владимирцова) названные залоговые суффиксы предстают во вполне утвердившемся, давно 'обкатанном' виде: huyaydaba 'был связан' [Поппе 1938: 188], kigden boluge ‘было сделано’ [Veitz, Lubsang 1992: 26], teberildube 'обнялись' [Поппе 1938: 344], jolgaldubai встретились [Veitz, Lubsang 1992: 20], bayasulcabai 'возрадовались (вместе)' [Veitz, Lubsang 1992: 17], abulcaba ol-
Суффиксы -оо, - $а a$, -ээ, залоговый характер которых отмечен А. М. Орловым в его грамматике, в современном бурятском языке получил своё дальнейшее развитие: с присоединением к ним суффикса -тай (и его вариантов) образовались формы страдательного залога на -аaтай, -оотой, -ээтэй (үҮдэн неэлгээтэй 'дверь открыта', Үнеэн hаалгаатай 'корова подоена'), и это — инновация сегодняшних дней: образовались двучленные страдательные конструкции, назначение которых - избежать обозначения субъекта в тех случаях, когда важен результат действия и не актуален его источник (или носитель), тем самым позволяя говорящему представить действие в абстрагированном от его производителя виде. ${ }^{2}$

jayi 'распределили добычу (между собой)' [Поппе 1938: 94], ogtebe 'отдан' [Veitz, Lubsang 1992: 41-42], abtaba 'взят' [Veitz, Lubsang 1992: 41, 42, 21], doroyitagulju 'подчинив' [Veitz, Lubsang 1992: 29]. О давней освоенности этих суффиксов древнемонгольским языком говорит то, что в «Мукаддимат-ал-Адаб» и «Сокровенном сказании» они используются в таких высокоупотребительных словах, как глаголы речи и служебные глаголы со значением «делать», «стать», «быть» и др., которых, как известно, в монгольских языках очень много и без которых редкое предложение обходится; в устойчивых словосочетаниях (tengri ujegdebei - mengri-te tagalagdaqu [Veitz, Lubsang 1992: 43] 'небом охраняем', 'небом облагодетельствован'), что тоже считается результатом частотности и длительности использования в узусе.

2 Внесение разнообразия в субъектно-объектные отношения в предложении - явление в бурятском языке совершенно новое. Если, скажем, в «Мукаддимат-ал-Адаб» в общем ряду однотипных единиц, не отличающихся большим разнообразием, стоят предложения типа Лихорадка схватила мужчину [Поппе 1938: 120], а страдательное значение большей частью передается с помощью вспомогательных глаголов: Спина животного стала с ссадиной [Поппе 1938: 96], Земля стала с травой (вместо покрылась травой) [Поппе 1938: 150], Высокий человек стал дурак (вместо Высокий человек был одурачен) [Поппе 1938: 96], Снег держал его [Поппе 1938: 149], Эта работа сделала меня печальным [Поппе 1938: 160], то на современном этапе синтаксис бурятского предложения получил развитие в сторону тематизации объекта путем его перевода в позицию подлежащего, и это вызвано прежде всего стремлением говорящего 
Суффиксы -оотой, -аатай, -ээтэй появились в бурятском языке, вероятно, под влиянием русского языка: дело сделано, письмо написано, дом построен (монгольским языкам глубоко чужда способность отрывать действие от его производителя).

Грамматика монголо-бурятского языка, составленная протоиереем А. М. Орловым в 1878 г., посвящена функционированию категории залога в разговорной стихии, при этом ценно то, что автор стремится передать языковой материал, свободный от тунгусоманьчжурского и китайского влияния, отразить «употребление и расположение слов родное - монгольско-бурятское, и сделать много опытов к написанию, склонению и спряжению слов на бурятский лад» [Орлов 1878: 8]

Наблюдения за категорией залога в бурятском разговорном языке на современном этапе его развития приводят к выводу о том, что

1) в стихии употребления всё труднее считать морфологические показатели залога однозначно передающими значение того или иного залога:

а) суффиксы -уул (юул) и -лга (-лгэ, -лго) побудительного залога могут иметь страдательное значение, и для дифференциации этих значений может быть привлечён семантико-синтаксический уровень языка. В побудительной конструкции субъект всегда является подлежащим, который заставляет, вынуждает, стимулирует объект выполнить названное сказуемым действие. В страдательной же конструкции наблюдается несоответствие субъекта подлежащему, означающее, что действие не исходит от субъекта. Несоответствие субъекта подлежащему, если оно имеет место в предложении, автоматически относит конструкцию к пассивной, даже если глагол имеет побудительную маркировку; ${ }^{1}$

сделать предложение более разнообразным, избежав тавтологии, более красивым, благозвучным, а назвав не само действие, но его результат («открыто», «схвачен», «взят»), сделать свою речь лаконичной, отточенной и в то же время экспрессивной.

1 Наблюдения за устной бурятской речью показывают, что разрешение данной путаницы кроется и в обращении к грамматически значимым семантическим категориям; для дифференциации пассивных и каузативных конструкций с одинаковым маркером, вероятно, полезно и рассмотрение референтного, ситуационного уров- б) достаточно часто -ldu с значением взаимного действия может быть заменено на форму совместного действия на $-l c a$ без ущерба для смысла предложения;

2) в современном бурятском языке значения залога нередко передаются синтаксическим способом. Для образования страдательной конструкции, например, используются глаголы болохо 'становиться', байха 'быть', болихо 'перестать', орохо 'заходить' и др.: адис хүртэхэ 'удостоиться благословения', аманда орохо 'попасть в рот', перен. 'поддаться (чьим-то) пустым обещаниям, позволить (кому-то) себя уговорить; алъбанда орохо 'попасть под чье-либо очарование', нулөө(н) узэхэ 'испытать чье-либо влияние', мэдэл доро байха 'быть в чьем-либо ведении';

3) в бурятском языке, как и в других монгольских языках, при передаче грамматических значений в слове часто наблюдается влияние лексического значения его основы - особенно в тех случаях, когда грамматическая категория не имеет специа-

ня, когда в поисках каузатора, реципиента каузации, объекта каузации нужно будет выявлять их экспликацию за пределами предложения, т. е. в тексте.

И у пассива, и у каузатива есть значение «позволить кому-л. совершить то или иное действие». В побудительной конструкции, в ситуации, когда исполнителя просят или ему приказывают выполнить действие, допускается только одушевленный исполнитель, способный воспринять сообщение о выполнении контролируемого, намеренного действия, способный разрешить, не возразить, согласиться (о пермиссиве, фактитиве, декларативе и др. (см.: [Недялков, Сильницкий 1969: 20-50]). Что касается страдательных конструкций, которые могут быть оформлены с помощью суффиксов побудительного залога -уул/юул — лга/лге, то они отличаются от побудительных конструкций прежде всего семантикой допущения и, обычно, имеющейся в контексте мотивации этого допущения: объект испытывает на себе благоприятные действия со стороны в силу желательности этого действия, его целесообразности; испытывает нежелательное действие, т. е страдает, в силу безразличного отношения, в силу объективных причин, из-за таких личных качеств, как халатность, безответственность, из-за оплошности, неподготовленности, неожиданности действия со стороны, его предрешенности, неизбежности. Ср.: Позволить купить вещь - Позволить врагу вторгнуться на свою территорию. 
лизированных, регулярных средств выражения.

Категория залога, в котором план выражения и план содержания асимметричны - наглядное тому подтверждение: в настоящее время всё чаще приходится говорить не столько о залоге, сколько о залоговости - функционально-семантическом поле, в котором образуются микрополя лексико-грамматических разрядов, объединенных общностью семантических признаков. Например, в сегменте страдательного залога можно выделить группу глаголов с суффиксом -рха (-pхэ, -рхо), которые можно назвать адверсативным пассивом (выражающим нежелательное воздействие) на пациенса: аляаһархаха 'страдать от обилия мух, быть донимаемым мошкарой'; бороорхохо 'страдать от ревматических болей, которые связываются с переменой погоды: выпадением снега, дождя, наступлением ненастья'; аягүйргэхэ 'страдать от неловкости положения', хуйтэрхэхэ 'страдать от холода', мүнгэгүйрхэхэ, моригүйрхэхэ 'страдать от безденежья, безлошадности'.

\section{ЛИТЕРАТУРА / REFERENCES}

Батожабай 1959 - Батожабай Д. О. Похищенное счастье. Роман. М.: Советский писатель, 1959. 404 c. [Batozhabay D. O. Pokhischennoe schast'e [The Stolen Happiness]. Novel. Moscow: Sovetskiy Pisatel', 1959. 404 p. (In Rus.)]

Дырхеева, Ринчинов 2005 - Дырхеева Г. А., Ринчинов О. С. Морфологическая структура слов в бурятском языке: лингвостатистическое описание (на материале художественного текста). Улан-Удэ, БНЦ СО РАН, 2005. 98 c. [Dyrkheeva G. A., Rinchinov O. S. Morfologicheskaya struktura slov v buryatskom yazyke: lingvostatisticheskoe opisanie (na materiale khudozhestvennogo teksta) [Buryat morphological structures: a statistic-linguistic analysis (a case study of fiction texts)]. UlanUde: Buryat Scientif. Center of RAS (Siber. Branch), 2005. 98 p. (In Rus.)]

Недялков, Сильницкий $1969-$ Недялков В. П., Сильницкий Г. Г. Типология морфологических и лексических каузативов. // Типология каузативных конструкций / ред. А. А. Холодович. Л.: Наука, 1969. С. 20-60. [Nedyalkov V. P., Silnitsky G. G. Typology of morphological and lexical causatives. Tipologiya kauzativnykh konstruktsiy [Typology of causative constructions]. A. A. Kholodovich (ed.). Leningrad: Nauka, 1969. Pp. 20-60. (In Rus.)]
Орлов 1878 - Орлов А. М. Грамматика монголо-бурятского языка. Казань: Типография М. А. Гладышевой, 1878. 269 с. [Orlov А. М. Grammatika mongolo-buryatskogo yazyka [A Buryat-Mongolian grammar]. Kazan: M. A. Gladysheva, 1878. 269 p. (In Rus.)]

Поппе 1938 - Поппе Н. Н. Монгольский словарь Мукаддимат-ал-Адаб. М.; Л.: Изд-во АН CCCP, 1938. 452 c. [Poppe N. N. Mongol'skiy slovar' Mukaddimat-al-Adab [Muqaddimat aladab: a dictionary of Mongolian]. Moscow; Leningrad: USSR Acad. of Sc., 1938. 452 p. (In Rus.)]

Раднаев 1965 - Раднаев Э. Р. Баргузинский говор // Исследование бурятских говоров. Вып. 1. Улан-Удэ: БНЦ СО РАН, 1965. C. 71-107. [Radnaev E. R. The Barguzin dialect. Issledovanie buryatskikh govorov [Studies of Buryat dialects]. Is. 1. Ulan-Ude: Buryat Scientif. Center of RAS (Siber. Branch), 1965. Pp. 71-107. (In Rus.)]

Рамстедт 1957 - Рамстедm Г. И. Введение в алтайское языкознание. М.: Иностр. лит., 1957. 254 с. [Ramstedt G. I. Vvedenie $v$ altayskoe yazykoznanie [An introduction to Altaic linguistics]. Moscow: Inostr. Lit., 1957. 254 p. (In Rus.)]

Санжеев 1941 - Санжеев Г. Д. Грамматика бурят-монгольского языка. М.; Л.: АН СССР, 1941. 188 c. [Sanzheev G. D. Grammatika buryat-mongol'skogo yazyka [A BuryatMongolian grammar]. Moscow; Leningrad: USSR Acad. of Sc., 1941. 188 p. (In Rus.)]

Санжеев 1964 - Санжеев Г. Д. Сравнительная грамматика монгольских языков. Глагол. М.: Наука, 1964. 266 с. [Sanzheev G. D. Sravnitel'naya grammatika mongol'skikh yazykov. Glagol [A comparative grammar of Mongolic languages: verb]. Moscow: Nauka, 1964. 266 p. (In Rus.)]

Цыдендамбаев 1979 - Цылендамбаев Ц. Б. Грамматические категории бурятского языка в историческо-сравнительном освещении. М.: Наука, 1979. 148 с. [Tsydendambaev Ts. B. Grammaticheskie kategorii buryatskogo yazyka vistorichesko-sravnitel'nom osveschenii [Buryat grammatical categories in a historicalcomparative perspective]. Moscow: Nauka, 1979. 148 p. (In Rus.)]

Шагдаров, Черемисов 2006 - Шагдаров Л. Д., Черемисов $K$. M. Бурятско-русский словарь. Улан-Удэ: ИМБиТ. Т. 1. 2006. 636 с. [Shagdarov L. D., Cheremisov K. M. Buryatskorusskiy slovar' [Buryat-Russian dictionary]. Ulan-Ude: Inst. for Mongolian, Buddhist and Tibetan Studies of RAS (Siber. Branch). Vol. 1. 2006. 636 p. (In Rus. and Bur.)] 
Шагдаров, Черемисов 2008 - Шагдаров Л. Д., Черемисов K. M. Бурятско-русский словарь. Улан-Удэ: ИМБиТ. Т. 2. 2008. 707 с. [Shagdarov L. D., Cheremisov K. M. Buryatskorusskiy slovar' [Buryat-Russian dictionary]. Ulan-Ude: Inst. for Mongolian, Buddhist and Tibetan Studies of RAS (Siber. Branch). Vol. 2. 2008. 707 p. (In Rus. and Bur.)]
Veitz, Lubsang 1992 - Veitz Hans-Peter, Lubsang Gendeng. Altan Tobci. Eine mongolische Chronik des XVII [The Altan Tobchi: a $17^{\text {th }}$ century Mongolian chronicle]. Text and index. Tokyo: Institute for the Study of Languages and Cultures of Asia and Africa, 1992. 278 p. (In Germ.)

\title{
A Grammar of Spoken Buryat-Mongolian by A. M. Orlov: Verb. The Category of Voice
}

\section{Polina P. Dambueva ${ }^{1}$}

${ }^{1}$ Ph.D in Philology (Doct. of Philological Sc.), Leading Research Associate, Department of Uralic and Altaic Languages, Institute of Linguistics of the RAS (Bldg. 1, 1, Bolshoi Kislovsky Bystr., Moscow, 125009, Russian Federation). ORCID: 0000-0003-1948-7149. E-mail: polina-dambueva@ mail.ru

\begin{abstract}
Materials. The article examines A Grammar of Spoken Buryat-Mongolian issued by A. Orlov in 1878. A. Orlov's Grammar was written as a practical guide to study the Buryat language. The work aims to revisit the category of voice within the Grammar in comparison with the facts of modern Buryat, to compare Grammar's language materials dealing with the category to present-day grammatical voice structures.

Goals. The paper ascertains that A. Orlov's Grammar contains quite precise characteristics of the Buryat verb, including voices of the verb, their morphological indicators. The illustrative materials indicate his sufficiently deep knowledge of lexical and grammatical features of the Buryat language.

In the Introduction to the 'Verb' section, A. Orlov divides verbs into primitives and derivatives, exemplifying the differences throughout extensive materials, revealing a deep understanding of the structure of Buryat verbs derived from nominal parts of speech, adverbs and particles which was extremely rare for a non-native speaker in those times.

When examining the language, the paper seeks to highlight A. Orlov's scientific approach to Buryat grammar studies: his Grammar considered all varieties of the Buryat voice, ways of expression, marking and partially - polysemy markers; it also considers the morphological indicators of the verb selected by A. Orlov as indicators of the voice. The analysis of the voices in modern Buryat revealed as follows: it is difficult to say that morphological indicators of the Buryat voices unequivocally convey meanings of the passive, or causative, or reciprocal, or any other voices. For example, suffixes of the causative (hortative) can have a passive meaning, and it may be necessary to turn to the semanticsyntactic level of the language to differentiate between the meanings.

Results. In modern Buryat, voice meanings are often transmitted in a syntactic or lexical way (e. g., reflexive meaning). The verbal suffixes listed in Orlov's Grammar received further development, their taxonomy was replenished, and the category of voice has been considered wider - including lexical, semantic, syntactic levels of the Buryat language, although after a century and a half after the release of the Grammar morphological indicators have basically remained unchanged.

The article draws conclusions about the need to consider the voice from the viewpoint of its multi-level expression; description of the understudied forms -ootey, eetey, -aatai which, in the author's opinion, arose under the influence of the Russian language.

In the Buryat language - like in other Mongolian languages when it comes to convey grammatical meanings within a word - the influence of the lexical meaning is often observed, especially in cases when the grammatical category has no specialized, regular means of expression. In the category of voice, the expression plan and the content plan are asymmetric, so nowadays one can say that it is the functional-semantic field that gives rise to lexical-grammatical microfields.
\end{abstract}

Keywords: A. Orlov, grammar, Buryat-Mongolian language, modern Buryat language, voice, category of voice (voiceness), grammatical indicators 